Grethe Heidi Bjerga, Marianne Kro Gausel, universitetslektor, UiS assisterende avdelingssykepleier, SUS
Margareth Gilje Heggland, avdelingssykepleier, SUS
Bente Rossavik, vei-

ledning,- etikk,- og stu-

dentkoordinator, SUS

\title{
Dokumentasjon ga bedre pleie
}

\author{
Ved å innføre Elektronisk Dokumentasjon av Sykepleie (EDS) \\ ble pleien til pasientene mer målrettet.
}

$\mathbf{N}$ ovember 2009 innførte Stavanger Universitetssjukehus (SUS) det elektroniske pasientjournalsystemet DIPS. Noen måneder senere ble Elektronisk Dokumentasjon av Sykepleie (EDS) modulen implementert. Parallelt med innføringen av EDS på sengeposten valgte vi å samarbeide med Universitet i Stavanger (UiS) om et dokumentasjonsprosjekt der målet var å bedre kvaliteten på den elektroniske dokumentasjonen. Prosjektet ble gjennomført i en ordinær sengepost med 23 senger i Kirurgisk Divisjon. Sengeposten er veiledningspost for sykepleierstudenter. I denne artikkelen har vi valgt å beskrive prosjektet, og dele erfaringer og oppdagelser vi gjorde underveis. Bakgrunnen for prosjektet var et ønske om å forbedre etablert dokumentasjonspraksis og oppnå varig endring. Vi ønsket også å fokusere på sykepleie som et selvstendig fag med selvstendig dokumentasjonsplikt.

\section{Utfordring}

Papirdokumentasjonen var i stor grad preget av standardiserte pleieplaner og sjekklister, ikke individualiserte pleieplaner forankret i sykepleierprosessen. Dokumentasjonen var ofte uoversiktlig og ikke dekkende i forhold til utøvelse og kvaliteten av pleien. Evalueringen bar preg av fortløpende rapport. Dokumentasjonen skal gjenspeile observasjoner, vurderinger, beslutninger og handlinger. Den skal være en beskrivelse av virkningen av iverksatte tiltak og kvaliteten på behandlingen. (1.)
Avdelingssykepleier er i samarbeid med assisterende avdelingssykepleier, ansvarlig for at sykepleien som utøves på sengepost er i tråd med faglig forsvarlig praksis. Dette ansvaret innebærer også at dokumentasjonen følger gjeldende juridiske krav og retningslinjer. I Helsepersonellloven $\$ 40$ 1. ledd heter det: «Journalen skal føres i samsvar med god yrkesskikk og skal inneholde relevante og nødvendige opplysninger om pasienten og helsehjelpen, samt de opplysninger som er nødvendige for å oppfylle meldeplikt eller opplysningsplikt fastsatt i lov eller i medhold av lov. Journalen skal være lett å forstå for annet kvalifisert helsepersonell» (2, s. 677).

Som ledere med faglig og administrativt ansvar er det vanskelig å prioritere tid nok til fagutvikling. Med innføringen av EDS og igangsetting av prosjektet ble vi forpliktet til å sette av tid til dokumentasjonsarbeid.

\section{Prosjektet}

I veiledningsposten har det vært et gjennomgående tema hvordan vi kan stimulere til fagutvikling og et høyt faglig nivå. I samarbeidsavtalen med UiS er det også krav om at det legges til rette for fagutviklings- og forskningsprosjekter. Vi ønsket derfor å samarbeide med UiS om dokumentasjonsprosjektet. Vi etablerte en prosjektgruppe bestående av universitetslektor, veiledning-, etikk og studentkoordinator i klinikken, assisterende/-og avdelingssykepleier. Gruppen startet arbeidet med å skrive prosjektplan som ble presentert for ledelsen ved UiS og SUS.

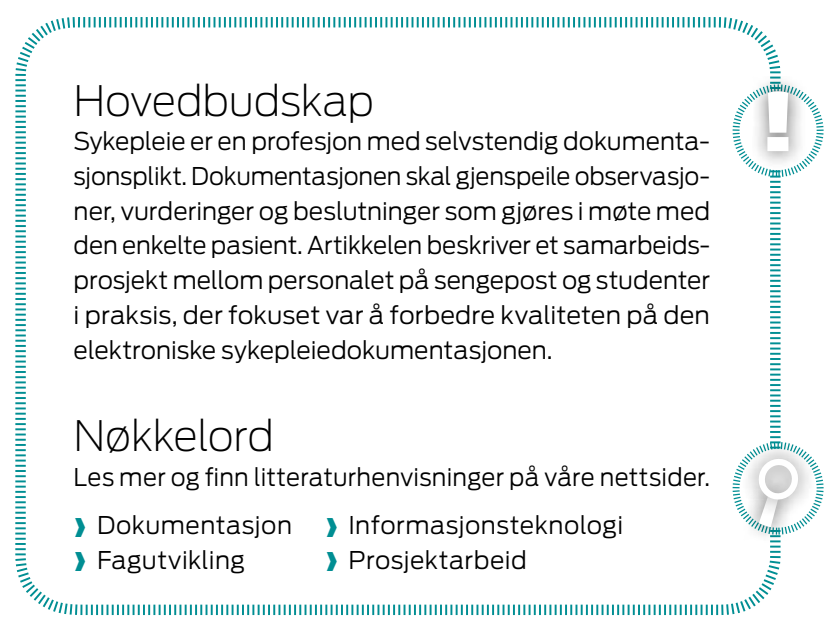

Vi valgte å ha et todelt fokus i prosjektet, der ledelsen ved assisterende avdelingssykepleier, fokuserte på personalets fagutvikling og kvalitet på dokumentasjonen, mens universitetslektor og veiledning-, etikk og studentkoordinator fokuserte på studentens læring.

Det var viktig for oss at prosjektet skulle gi anledning til å reflektere over og vurdere den elektroniske sykepleierdokumentasjonen. For å sikre varig forbedring av dokumentasjonen var det viktig å knytte refleksjonen til praksis. (3). Personalet og sykepleierstudenter fikk godt utbytte av prosjektet gjennom felles deltakelse. Lave og Wenger kaller dette et praksisfellesskap der læring finner sted i de sosiale strukturene 
mellom novise og ekspert, og betegner denne prosessen som legitim perifer deltakelse. (4).

\section{Praktisk gjennomføring}

Prosjektperioden gikk over studieåret 2009-10. Vi hadde totalt 16 prosjektmøter. Møtene ble holdt annenhver uke og varte i halvannen time. Deltakerne på møtene var to studenter, to fra personalet (sykepleier/hjelpepleier) samt to fra prosjektgruppen. Alle studentene som var i praksis i løpet av perioden deltok i prosjektet, samt 31 av 41 fra personalgruppen. I møtene vurderte vi sykepleiedokumentasjonen til en vilkårlig valgt pasient, som en av deltakerne hadde ansvar for den dagen.

I prosjektplanleggingen utarbeidet vi et skjema som behandlingsplanene ble vurdert ut fra. Møtene ble lagt til et lukket rom med projektor. Møtene var preget av gjensidig dialog, med vekt på læring, refleksjon og faglige diskusjoner - uten kritikk av dokumentasjonen. Behandlingsplanen ble vurdert i henhold til vurderingsskjema og fortløpende revidert på prosjektmøtene. Møtene ble ledet av en fra prosjektgruppen.

\section{«Den som har ansvaret for pleien til pasienten fikk hovedansvaret for å doku- mentere.»}

Alle deltakerne i prosjektet var underlagt taushetsplikt og tilknyttet sengeposten. Prosjektet involverte ikke pasienter, og pasientopplysninger ble ikke registrert eller lagret i noen deler av perioden. Flere i prosjektgruppen har veilederutdanning og flere års erfaring med å arbeide med gruppeprosesser.

\section{Teori møter praksis}

Arbeid med å innføre gode dokumentasjonsrutiner er ledd i kvalitetsutbedringsarbeidet. Elektronisk dokumentasjonen er et enkelt kvalitetssikringsredskap for å vurdere sykepleien til den enkelte pasient og effekten av behandlingen. (5). En behandlingsplan er en systematisk plan over pasientens sykepleiediagnoser, mål og tiltak. Gjennom klassifikasjonssystemer har sykepleiebegreper blitt systematisert i fenomener. Disse klassifikasjonssystemene bidrar til en faglig standard bygd på sykepleietenkning, og en problemløsende tilnærming til pasientens problemer. Dette verktøyet sikrer faglighet, kontinuitet og kvalitet i sykepleie til pasienten og vil ivareta sykepleieprosessen dersom det brukes slik intensjonen er.

Ved innføringen av EDS på SUS fikk sengepostene i oppgave å utarbeide veiledende behandlingsplaner for aktuelle pasientgrupper med utgangspunkt i NANDA-diagnoser og NIC-tiltak. En veiledende behandlingsplan er preformulert oversikt over sykepleierdiagnoser, mål og relevante tiltak eller forordninger som kan være aktuelle for en gitt gruppe pasienter, for eksempel preoperative pasienter. (6). Utfordringen med kodeverket som er utviklet i USA, er at begrepene er fremmedartete og generelle. Ved å individualisere diagnoser, mål og tiltak vil behandlingsplanen gi en god oversikt over pasientens individuelle behov for sykepleie.

\section{Læringsarena}

Vi fikk mange spennende faglige diskusjoner i prosjektmøtene. Revideringer ble foretatt i behandlingsplanen etter diskusjoner mellom personal og studenter. Deltakerne var likeverdige medlemmer i diskusjonen og utvekslet erfaringer og teoretisk kunnskap i et felles forum. I etterkant av prosjektmøtene så vi at diskusjonene fortsatte på sengepost. Hummelvoll beskriver begrepet kunnskap-i-handling. Dette innebærer at kunnskap skapes i og for praksis. Kunnskapen bidrar til nye ferdigheter og praksis (7).

Alle behandlingsplanene som ble vurdert hadde sykepleiediagnose, mål og tiltak. Hovedsakelig var disse utarbeidet fra veiledende behandlingsplaner. I journalene der behandlingsplanene ikke var oppdaterte og reviderte, bar evalueringen preg av fortløpende rapport. Dokumentasjonen ble da uoversiktlig og det ble vanskelig å danne seg et godt bilde av pasienten. I evalueringen av tiltakene var det skrevet en del informasjon som med fordel kunne vært omskrevet som tiltak. Informasjonen ville da blitt enklere å finne og sikret bedre kontinuitet i pleien.

I de veiledende behandlingsplanene er tiltakene systematisert på en slik måte at et tiltak forekommer under flere problemområder. Når man velger flere tiltak med tilnærmet lik betydning, blir behandlingsplanene lange, uoversiktlige og lite brukervennlige. Dette hadde deltakerne sett og erfart i praksis, men syntes det var vanskelig å gjøre noe med det. Den faglige diskusjonen og det konkrete arbeidet som ble utført under prosjektmøtene var av avgjørende betydning for læringen $(3,4)$. Vi diskuterte og individualiserte diagnoser, slo sammen og spesifiserte tiltak. Behandlingsplanene ble kortere og mer oversiktlige. Dette førte til en økt forstå- else for hensikten med en oppdatert behandlingsplan der evalueringsnotatet ble evaluering av iverksatte tiltak, og ikke en nedtegnelse av dagens hendelser. Arbeidsmetoden fungerte også som en praktisk undervisning i funksjonaliteten i DIPS.

\section{Dokumentasjonsrutiner}

Sykepleien på sengeposten er organisert etter gruppesykepleieprinsippet med en gruppeleder med hovedansvar for medikamenter og legevisitt. I etterkant av prosjektmøtene ble det diskusjon om hvem som er ansvarlig for å dokumentere. Det viste seg at det ofte ble gruppelederen som oppdaterte og evaluerte behandlingsplanen, og ikke nødvendigvis det personalet som hadde ansvaret for pleien til pasienten den aktuelle vakten.

Dette førte til en diskusjon om organisering av pleien og hvem som har ansvar for å dokumentere hva. I etterkant kom det frem at ulike sykepleiere hadde lagt til seg ulike arbeidsvaner i forhold til dokumentasjon. I Helsepersonell loven heter det at «Den som yter helsehjelp, skal nedtegne eller registrere opplysninger som nevnt i \& 40 i en journal for den enkelte pasient.» (2, s. 677). Det kan være utfordring når flere med ulik kompetanse samarbeider om pleien til pasienten. Vi ble enige om at den som har ansvaret for pleien til pasienten har hovedansvaret for å dokumentere.

Ved innføringen av EDS ble det lagt føringer for hvordan man skal gi muntlig rapport fra behandlingsplanen. Ikke alle sykepleierne bruker behandlingsplanen i den muntlige rapporten ved vaktskifte. Faren er da stor for at viktig informasjon faller bort. Dette er spesielt viktig hvis personalet ikke kjenner pasientene. For å synliggjøre, samt bidra til gode rutiner i praksis, tilbyr assisterende eller avdelingssykepleier seg å gi muntlig morgenrapport fra behandlingsplanen. I de tilfellene der planen trenger revidering bemerker man dette og tilbyr personalet hjelp til dette. Det er et enkelt og effektivt tiltak for å vurdere kvaliteten på dokumentasjonen.

\section{Konklusjon}

I løpet av året med prosjektet så vi en gradvis forbedring av dokumentasjonen. Blant annet ble sykepleiediagnosene mer individualiserte og tiltakene mer konkrete. Dette har motivert oss til å fortsatt fokusere på elektronisk dokumentasjon av sykepleie. Vi har derfor videreført dokumentasjonsmøtene som en integrert del av fagutviklingen.

Dokumentasjonsprosjektet var spennende 


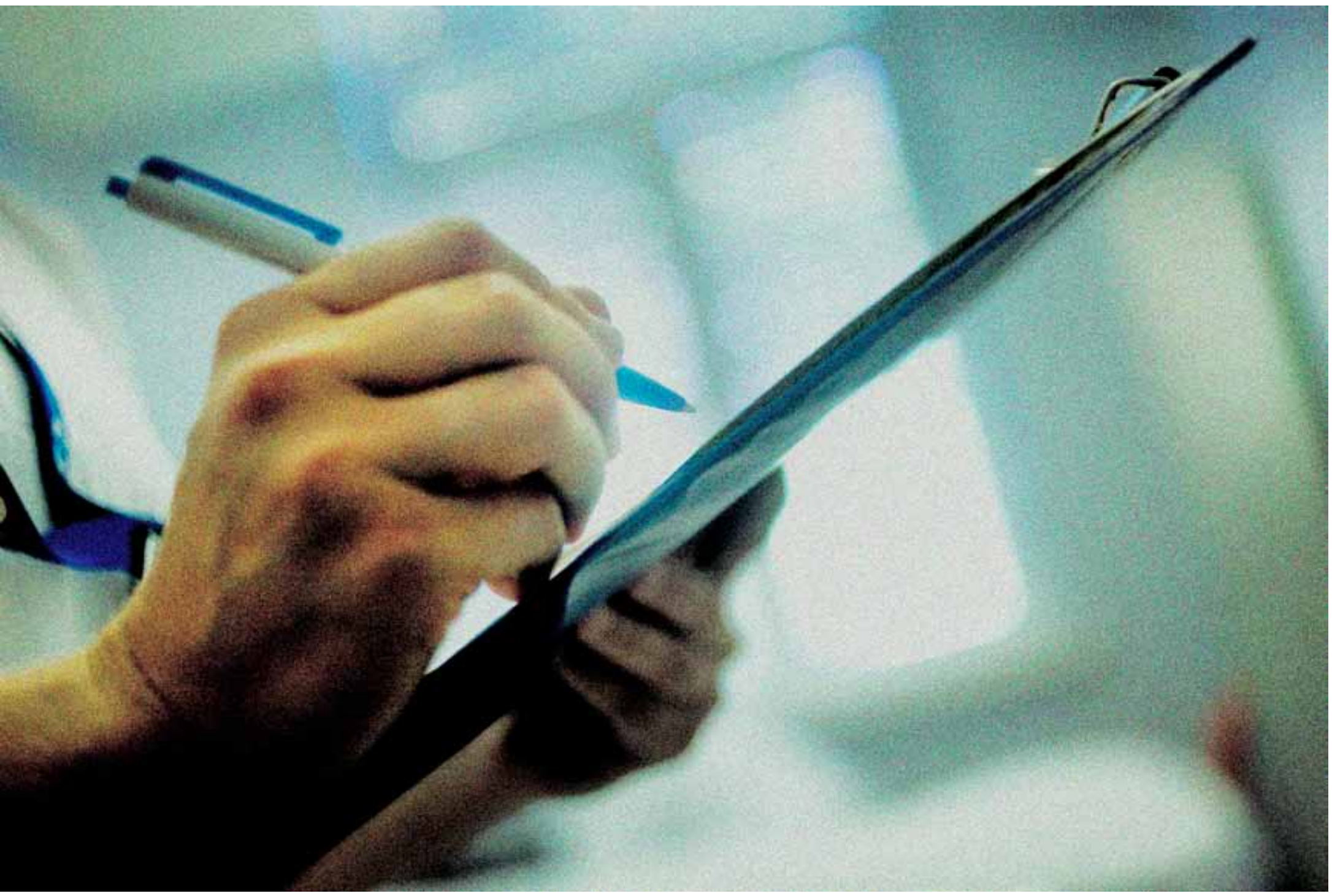

DOKUMENTERER PLEIEN: Dokumentasjon skal gjenspeile sykepleiers observasjoner, vurderinger, beslutninger og handlinger. Arkivfoto: Bo Mathisen.

og satte i gang mange prosesser. Vi lærte og oppdaget underveis. Personalet som har deltatt i prosjektet gir uttrykk for at det var lærerikt delta på møtene. Det er umulig å diskutere dokumentasjon uten å diskutere fag. Studentene sier at prosjektmøtene også fungerer som verdifull undervisning i elektronisk dokumentasjon, noe de har savnet på universitetet.

Som ledere og deltakere i prosjektgruppen sikret vi at prosjektet ble forankret i sengeposten. Vi var motiverte for å prioritere tid og de nødvendige ressurser som krevdes for å gjennomføre prosjektet. Prosjektet ga oss som faglige ledere god kompetanse på elektronisk dokumentasjon og de tekniske funksjonene i programmet. Det har vært givende å sette av tid til faglige diskusjoner i en hverdag preget av administrasjon. Dokumentasjon er et spennende felt og gir et godt bilde av hvilke pleieressurser som kreves i pasientbehandlingen.

Vi har erfart at man må fokusere på dokumentasjon for å ivareta og kvalitetssikre pasientens behov for sykepleie. Personalet trenger tid til å reflektere over dokumentasjonen, undervisning og tid til å lære å bruke et elektronisk verktøy. Godt samarbeid, vilje til forandring, evne til prioritering i hverdagen, er den beste pådriveren for faktisk å oppnå en forbedring. IIII

\section{REFERANSER}

Heggdal K. Sykepleiedokumentasjon. Oslo: Gyldendal Akademisk, 2006. http://helsedirektoratet.no/publikasjoner/helsepersonelloven-med-kommentarer/Publikasjoner/Helsepersonelloven\%20med\%20kommentar.pdf (september. 2011)

3. Hummelvoll JK. Handlingsorientert forskningssamarbeid - Teoretisk begrunnelse og praktiske implikasjoner. Norsk Tidsskrift for Sykepleieforskning. 2006; 1: $17-30$.

4. Lave, J og Wenger, E. Situert læring og andre tekster. København: Hans Reitzels Forlag, 2007.

5. Sandvand E, Vabo G. Dokumentasjon i sykepleien. En basisbok i faglig og juridisk forsvarlig dokumentasjon. Kristiansand: Høyskole Forlaget, 2007. http://www.dips.no/nor/vare-losninger/klinisk-dokumentasjon/ behandlingsplan?lang=nor, (september 2011).

7. Hummelvoll JK, Andvig E, Lyberg A. Etiske utfordringer i praksisnær forskning. Oslo: Gyldendal Akademisk, 2010.

Fagartikler kan sendes til torhild.apall@sykepleien.no 